\title{
Assessment of the Risk of Toxicity of Fish in the River Sô by Contamination in Heavy Metals (Southern Benin, West Africa)
}

\author{
Florence Tohozin1, Waris Kéwouyèmi Chouti2,3*, Nafiou Chitou², \\ Ringo Fernand Avahounlin1, Carine Nelly Kélomè ${ }^{4}$, Vissin W. Expédit ${ }^{5}$
}

\footnotetext{
${ }^{1}$ Chaire Internationale de Physique Mathématique et Applications (CIPMA CHAIRE-UNESCO, FAST, UAC), Cotonou, Benin ${ }^{2}$ Laboratory of Inorganic Chemistry and Environment (LAICE), Faculty of Science and Technology (FAST), University of Abomey-Calavi, Abomey-Calavi, Benin ${ }^{3}$ Laboratory of Applied Hydrology (LAH), National Institute of Water (NIW), University of Abomey-Calavi, Abomey-Calavi, Benin ${ }^{4}$ Département des Sciences de la Terre, Université d'Abomey-Calavi, Abomey-Calavi, Benin ${ }^{5}$ Institut de Géographie, de l'Aménagement du Territoire et de l'Environnement (IGATE, UAC), Abomey-Calavi, Benin Email: tohozinf@yahoo.fr, *warischouti@yahoo.com, ${ }^{\star}$ waris.chouti@uac.bj, chitounafiou@gmail.com, allouboss@gmail.com, nkelome@yahoo.fr
}

How to cite this paper: Tohozin, F. Chouti, W. K., Chitou, N., Avahounlin, R. F., Kélomè, C. N., \& Expédit, V. W. (2018). Assessment of the Risk of Toxicity of Fish in the River Sô by Contamination in Heavy Metals (Southern Benin, West Africa). Journal of Geoscience and Environment Protection, 6, 202-215. https://doi.org/10.4236/gep.2018.612017

Received: November 10, 2018 Accepted: December 26, 2018 Published: December 29, 2018

Copyright $\odot 2018$ by authors and Scientific Research Publishing Inc. This work is licensed under the Creative Commons Attribution International License (CC BY 4.0).

http://creativecommons.org/licenses/by/4.0/

\section{cc) (i) Open Access}

\begin{abstract}
The purpose of this study is to assess the state of contamination of fish in the Sô River by trace metal elements including Zinc, Lead, Cadmium, Copper and Arsenic. Water samples and four species of both sexes (Clarias anguillaris, Kribia kribensis, Tilapia guineensis and Eleotris vittata) were collected and analyzed. The $\mathrm{pH}$, temperature and values of the chemical species present in the water of the Sô River characterize an ecosystem favorable to the growth of aquatic species. The Metallic Traces Elements (MTE) concentrations vary from one fish species to another and depend on the sex and age of the animal. Zinc and copper are more concentrated in males than females with the exception of copper in Tilapia. The $\mathrm{Pb}$ concentration is higher in young Kribia and Clarias as well as $\mathrm{Zn}$ and $\mathrm{Cd}$ in young Tilapia. The concentrations in $\mathrm{Cd}$ and $\mathrm{Pb}$ are well above the European standards and those in the Republic of Benin, worrying results that express a health toxicity risk related to the consumption of fish of the river Sô.
\end{abstract}

Keywords

Health Toxicity Risk, Sô River, Metallic Traces Elements, Fish

\section{Introduction}

The development of the industry, the strong growth and the strong demographic 
growth, the urbanization, associated with the intense agropastoral activities are real and constant sources of pollution of the ecosystems. In fact, pollutants dumped in nature, without prior treatment, increase the rate of pollution of the environment (Ouédraogo, 2016). This pollution poses a clear risk to aquatic organisms and is therefore a danger to human health (Chouti et al., 2011). It is irrefutably accepted that the well-being of the human community is dependent on its environment and the measures it takes to preserve it, to protect it. This protection includes, among other things, knowledge of the types of pollutants in the ecosystem and their fate in the environment. And the Metallic Traces Elements (MTE) are among the major pollutants of the environment as much by the ubiquitous character of their presence within the biosphere as by their toxicity and their bioaccumulation potential in several aquatic species, inducing devastating effects (Katemo et al., 2010).

MTE can be very dangerous to the health of humans and other animals and plants when they are present in the environment at high concentrations (Fakayode, 2005). Living organisms can accumulate pollutants (including trace elements) at concentrations greater than those of their biotope (Tabinda et al., 2010; Ogindo, 2001).

It should be noted that Sô River is under a strong demographic pressure due to its wetland situation. As a result, it has become a receptacle for solid and liquid waste, numerous pig and cattle excrements and finally hydrocarbons (oil, gasoline, diesel, motor oil) (Kiossa, 2011) resulting from fraud. These different wastes are sources of various contaminations including those related to MTE in an ecosystem. However, fishing and trade in fish products are a source of livelihood, food and employment for many men and women.

The objective of this study is to diagnose the contamination of fish species by the $\operatorname{MTE}(\mathrm{Zn}, \mathrm{Cu}, \mathrm{Cd}, \mathrm{Pb}$ and $\mathrm{As})$. Thus, it was necessary to evaluate the degree of contamination according to the sex and the age of four fish species of the Sô River.

\section{Materiel and Methods}

\subsection{Study Framework}

Long of $84 \mathrm{~km}$, Sô River has its source in Lake Hlan and is connected to the Ouémé River by backwaters. It covers the scale of the municipality of Sô-Ava which it forms the watershed. Throughout this slope, local residents practice important agropastoral activities (potatoes, cassava, corn and crops). They use fertilizers. The herd (pigs and oxen) is left on the banks. Similarly, for their fishing activities, many branches are used for the realization of acadjas, which abounds and clutters the river. And finally, the fraudulent traffic of hydrocarbons is observed daily with frequent accidents which make pour huge quantities of these harmful products.

\subsection{Sampling}

Water and fish samples were collected on August 29, 2018 at four different 
points along the main stream (Figure 1). Thus, just after the arrival of the fishermen on the shore, four species of commonly caught fish and, consequently, the most consumed by the local and surrounding population, were sampled at the rate of three individuals per species. The water from the river is immediately taken in the village corresponding to the throwing of nets. The fish come from the catch of the artisanal fishery. It uses a variety of gear and fishing techniques

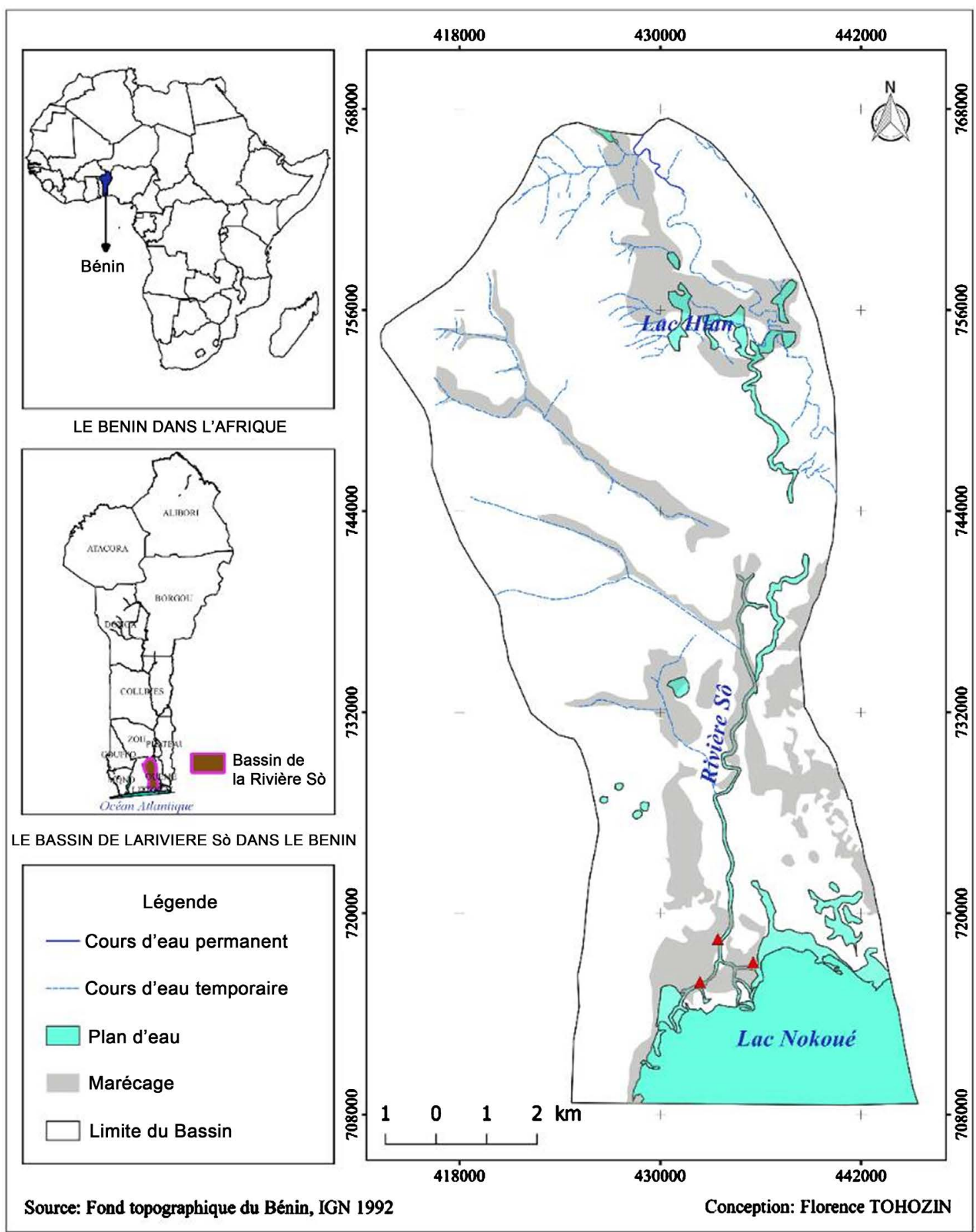

Figure 1. Geographical location of the study area. 
including gillnets (10 to $100 \mathrm{~mm}$ mesh stretched), traps, baited single and composite lines (longlines) and dam nets. Each fish species is identified according to the taxonomic identification guides of West African fish (Lévêque, 1990, 1992). The fish samples are measured and weighed respectively with an ichthy meter (to the nearest $\mathrm{mm}$ ) and a KERN electronic scale (0.1 g accuracy). Plate 1 presents the photograph of the fish species concerned. Their scientific and local identifiers are mentioned.

Analysis of the water samples: The water samples were taken in double-capped polyethylene bottles with a capacity of $1000 \mathrm{~mL}$, stored in a cooler at $4^{\circ} \mathrm{C}$ and returned to the laboratory. During sampling, a suitable measuring device is used: a Secchi disk; a multi parameter, Model SX736 pH/mV/Conductivity/DO Meter. With this device, the physical parameters are measured on the spot. In the laboratory, chemical parameters were measured using a DIONEX ICS-1000 ion chromatograph at the National Public Health Laboratory.

Analysis of fish samples: At sampling, the following parameters, weight and height, were determined before dissection. The fish, once thawed, were chipped, the viscera emptied, and then dissected. We took from each fish approximately $200 \mathrm{~g}$ of flesh which was then pounded.

Analysis of MTE in Fish: The MTE were extracted from the soluble solutions of flesh obtained above as follows: a mass of between $0.10-0.5 \mathrm{~g}\left(\mathrm{P}_{\text {mineral }}\right)$ of flesh of each sample was weighed in a school $100 \mathrm{ml}$ previously tarred; $4 \mathrm{ml}$ of $95 \%$ sulfuric acid $\left(\mathrm{H}_{2} \mathrm{SO}_{4}\right)$ is added. The whole was heated to boiling on a hot plate (physiochemical hood) for about an hour. After heating, hydrogen peroxide was added to bleach the solution. After cooling, the solution was filtered into a 100 $\mathrm{ml}$ flask, on ordinary Whatman filter paper. The volume was completed to the mark with distilled water. The samples were kept closed in vials, cool at $4^{\circ} \mathrm{C}$, until dosing. The arsenic, copper and zinc assay was performed by neutralization of the mineralizer. In fact, $20 \mathrm{~mL}$ of the mineralized material is neutralized and

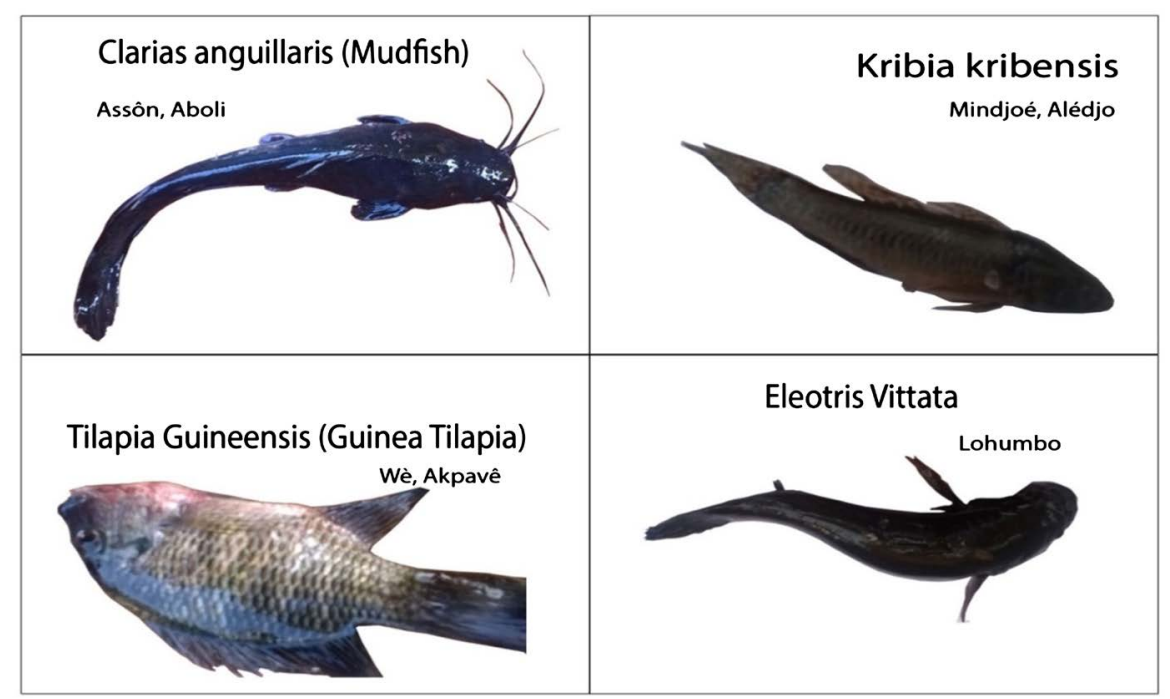

Plate 1. Photograph of sampled fish species. 
supplemented to twice the starting volume by adding $5 \mathrm{~N} \mathrm{NaOH}$ to a $\mathrm{pH}$ value of between 4 and 5 . The lead and the cadmium are determined by the Dithizone method.

Figure 2 describes the methodology used for metal analyzes in fish.

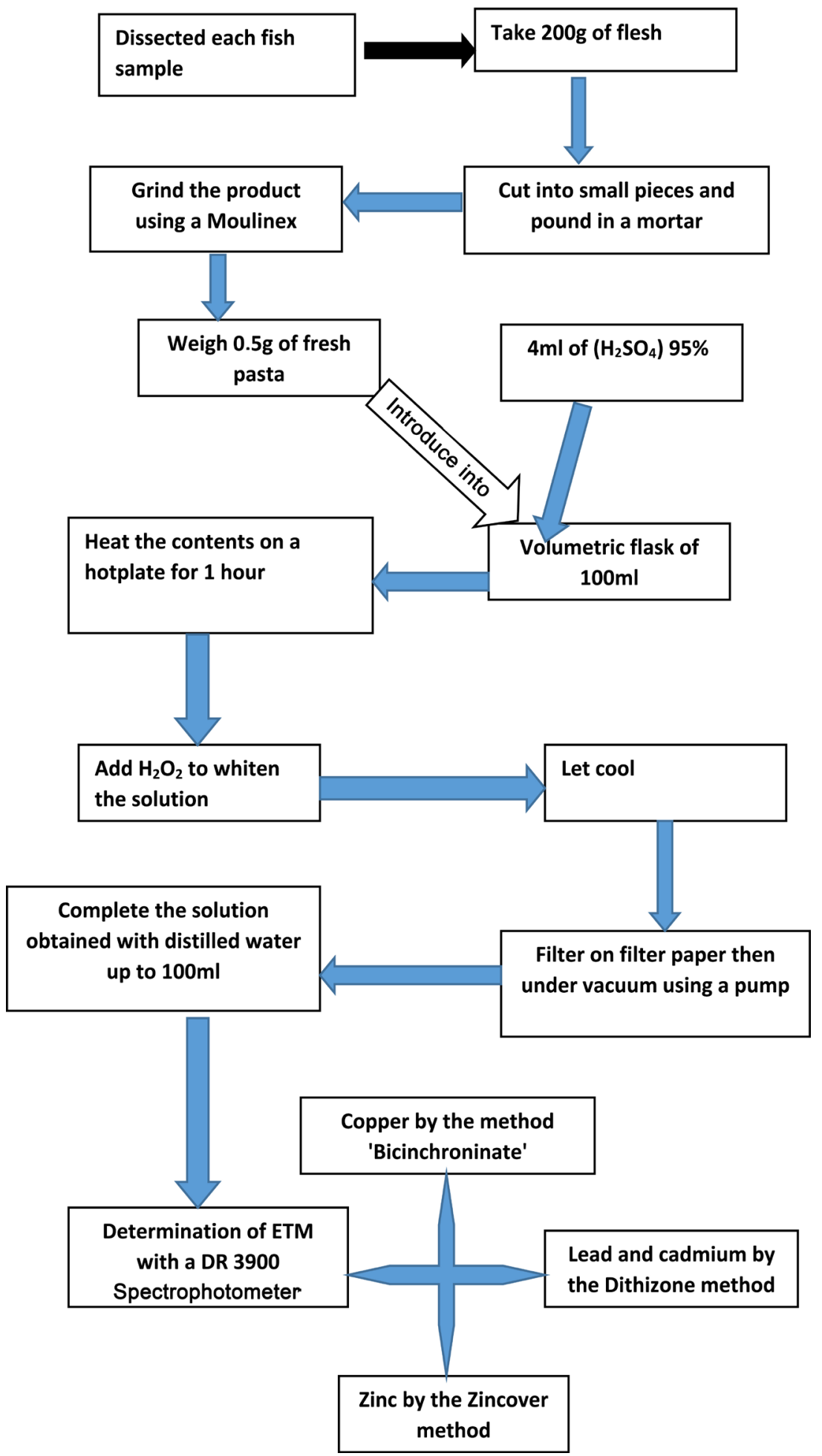

Figure 2. Diagram describing the methodology adopted. 


\section{Results and Discussion}

\subsection{Results}

\section{PHYSICO-CHEMICAL PARAMETERS OF WATER SAMPLES}

The following figures present the results of analyzes of the water from which the fish are derived.

From Table 1, the parameter values are almost identical to the levels of the three sampling sites. The $\mathrm{pH}$ of the water is between 6.51 and 6.85; the peak temperature is around $27.73^{\circ} \mathrm{C}$, the average value of TDS is $99 \mathrm{mg} / \mathrm{L}$.

Analysis of Figure 3 shows that the chloride ion content is higher than the other anions. The highest content of chloride ions is observed at the So-AVA site, as for the $\mathrm{HCO}_{3}^{-}$ions, the highest content is recorded on the site Havè.

Figure 4 shows the variation of fluoride and phosphate ions. Sochanhoue is richer in phosphates whereas the fluoride ions are abscent. Fluoride ions are higher at So-AVA.

The concentration of the iron ion (Figure 5) is almost identical at all three sites as well as that of the ammonium ion. Calcium ions are important with a higher concentration in So-AVA. Calcium and magnesium ions give the water a high degree of hardness. The content of dissolved oxygen is very low, which can make oxidation reactions in the medium difficult.

The high value of the hardness observed in Figure 6 confirms the content of $\mathrm{Mg}^{2+}$ and $\mathrm{Ca}^{2+}$ ions reported above.

Table 1. Physicochemical parameters.

\begin{tabular}{ccccc}
\hline & $\mathrm{pH}$ & $\mathrm{CE}(\mu \mathrm{S} / \mathrm{cm})$ & $\mathrm{T}\left({ }^{\circ} \mathrm{C}\right)$ & $\mathrm{TDS}(\mathrm{mg} / \mathrm{L})$ \\
\hline So-AVA & 6.55 & 98.2 & 26.9 & 98 \\
Havè & 6.51 & 99.13 & 27.3 & 99 \\
Sochanhoué & 6.51 & 102 & 29 & 100 \\
\hline
\end{tabular}

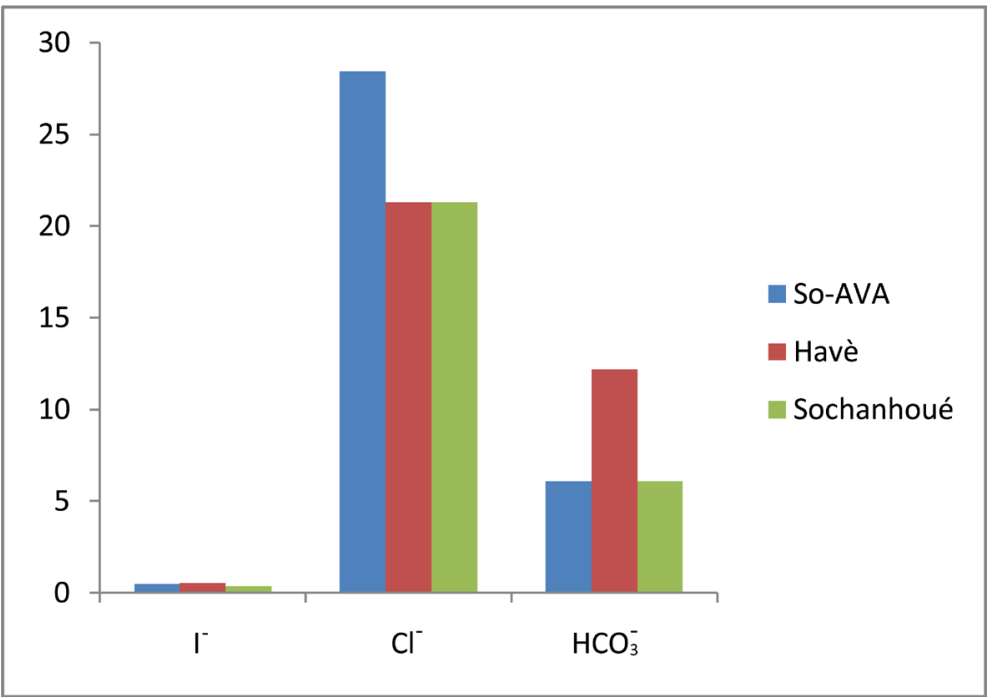

Figure 3. Chloride, iodide and hydrocarbon ion content. 


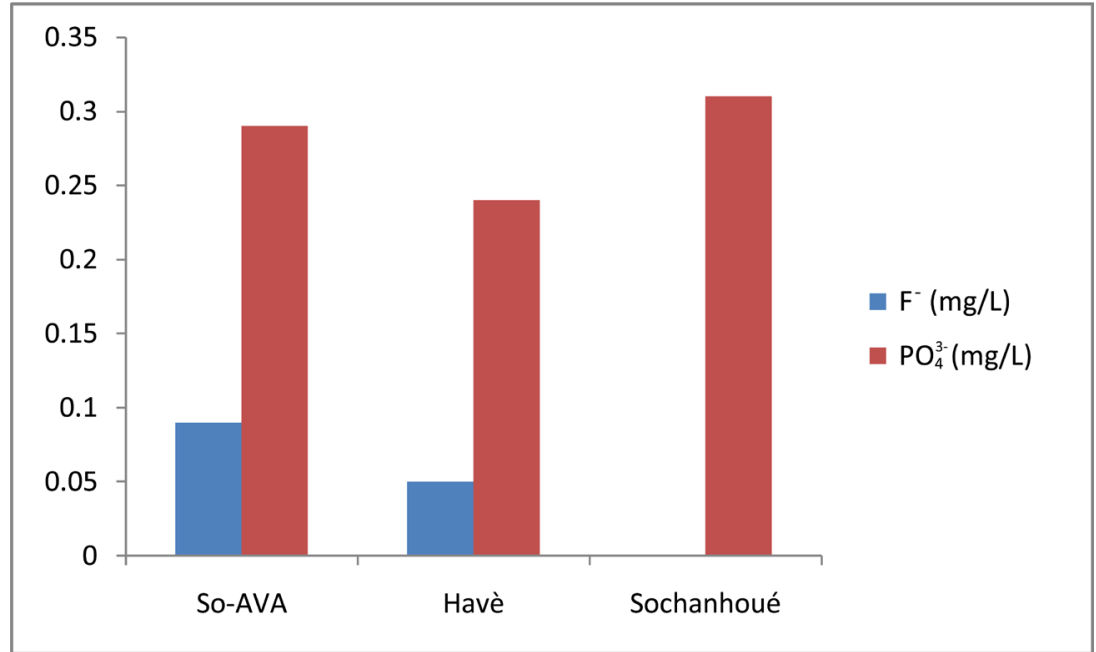

Figure 4. Fluoride and phosphate ion content.

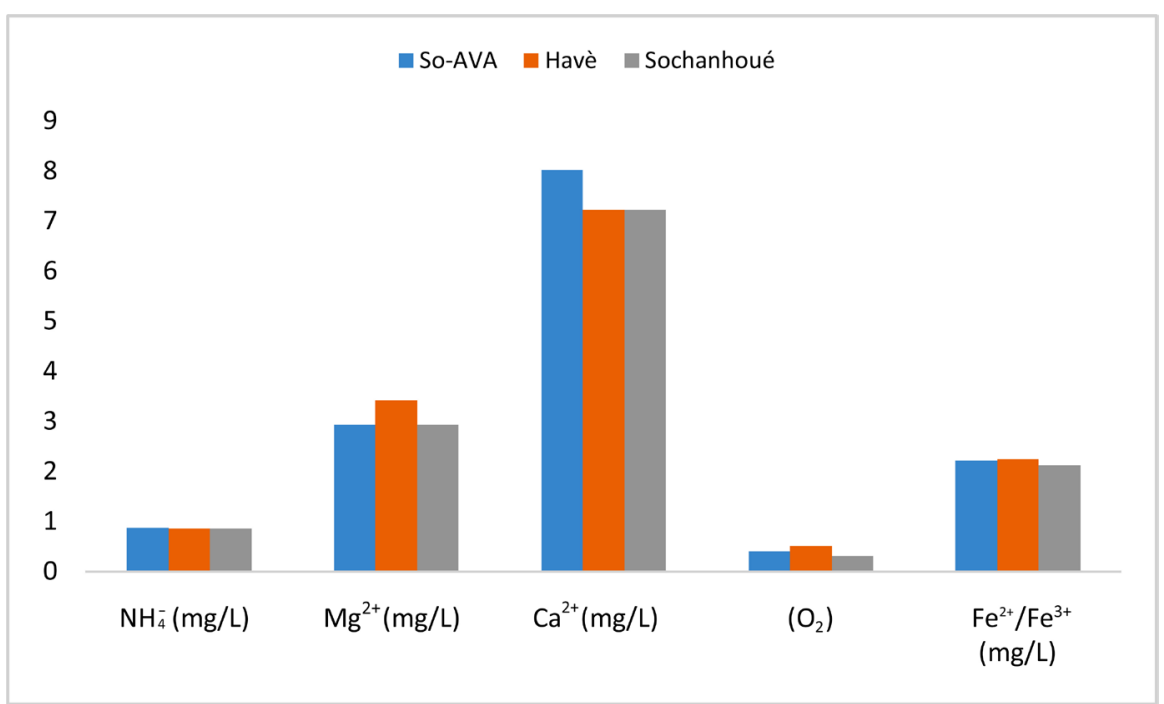

Figure 5. $\mathrm{Fe}^{2+} / \mathrm{Fe}^{3+}, \mathrm{Mg}^{2+}, \mathrm{Ca}^{2+}, \mathrm{O}_{2}, \mathrm{NH}_{4}^{+}$content.

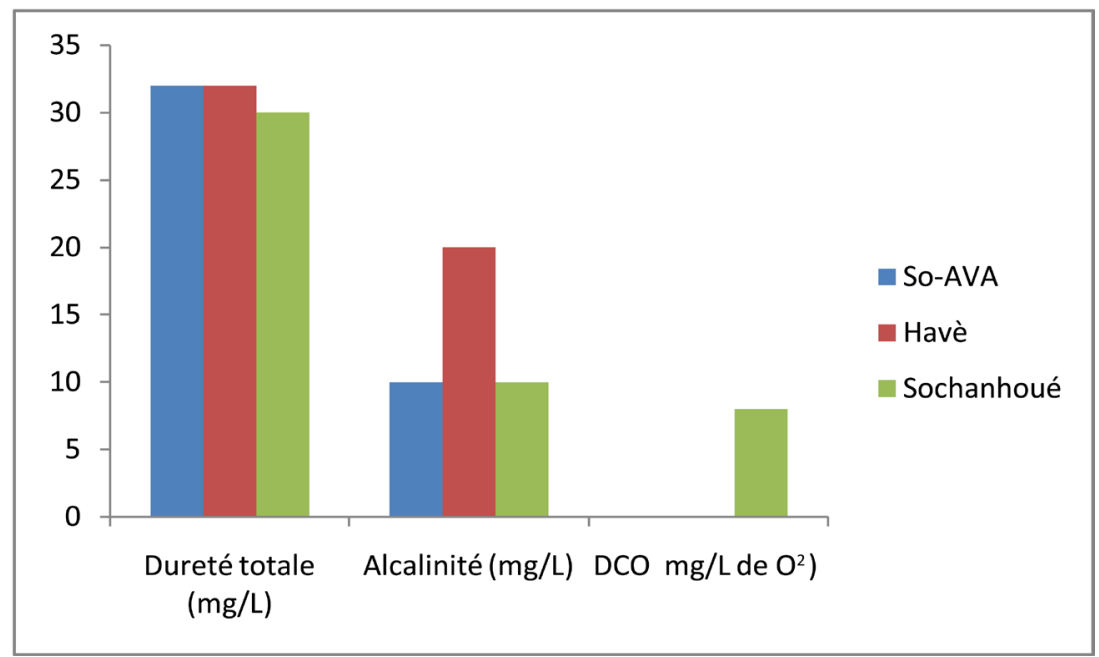

Figure 6. Variation in total hardness, alkalinity and chemical oxygen demand. 
For Kribias and Tilapia, the male has a size and a weight higher than the female whereas for Claris and Eleotris, it is the opposite (Table 2). The size of the fish is proportional to their weight.

For Kribia, Zinc and Cadmium are more concentrated in the male, Copper in the middle fish and Lead in the youngest (Figure 7).

For Tilapia, Zinc and Cadmium are more concentrated in the youngest, Lead in the male and Copper in the female (Figure 8).

For Eleotris, copper and zinc are more concentrated in males, lead and Cadmium in females (Figure 9).

Table 2. Size and weight of fish.

\begin{tabular}{cccc}
\hline Fishes & Category & Size $(\mathrm{cm})$ & Weight $(\mathrm{g})$ \\
\hline \multirow{3}{*}{ Kribia } & Male & 9.5 & 10.53 \\
& Female & 10.5 & 12.975 \\
& Mean & 7.3 & 5.72 \\
& Youngest & 6 & 3.37 \\
Tilapia & Male & 19.5 & 113.88 \\
& Female & 20 & 127.77 \\
& Mean & 14 & 47.33 \\
& Youngest & 7.7 & 8.2 \\
& Male & 46 & 469.05 \\
& Female & 35 & 278.77 \\
& Mean & 29 & 170.4 \\
& Youngest & 25 & 114.67 \\
& Male & 18 & 82.9 \\
& Female & 15 & 49.47 \\
& Mean & 8 & 7.73 \\
\hline
\end{tabular}

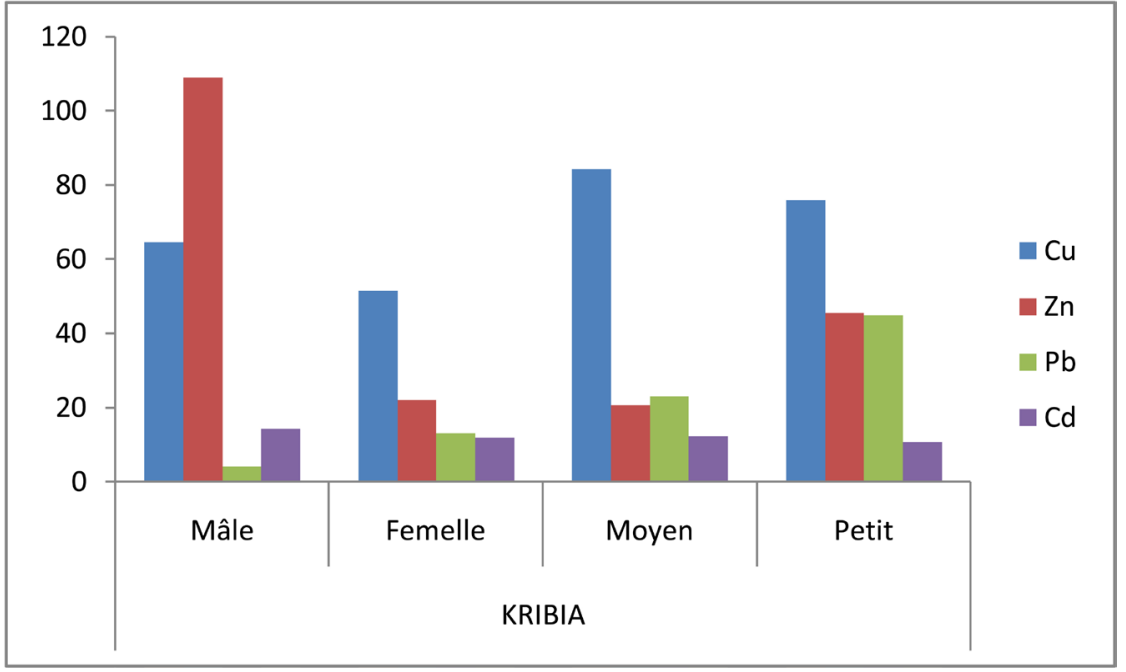

Figure 7. Variation of MTEs in Kribia. 


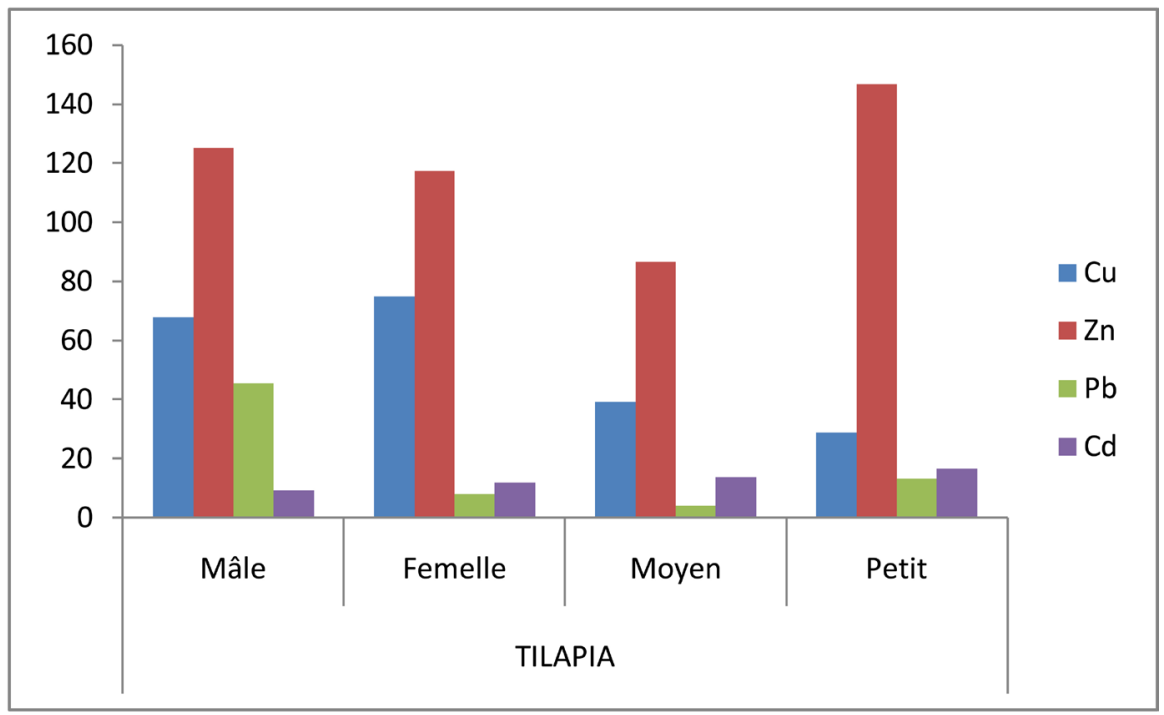

Figure 8. Variation of MTE in Tilapia.

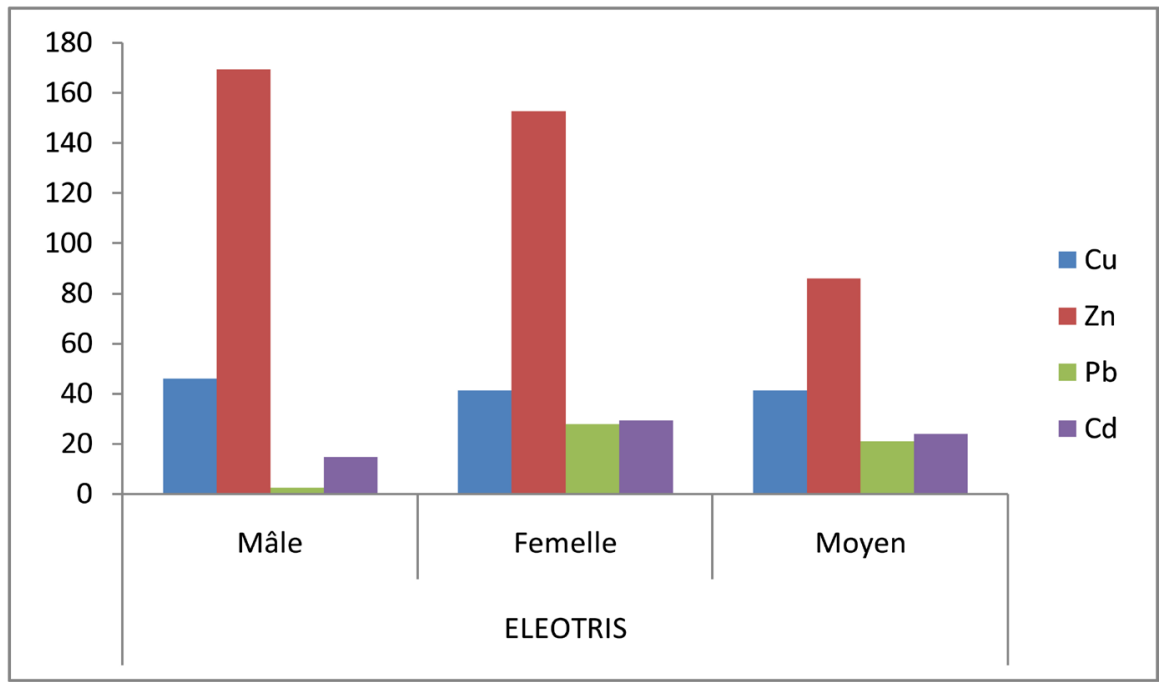

Figure 9. Variation of MTE in Eleotris.

For Clarias, copper and zinc are more concentrated in the middle fish, lead in the smaller and Cadmium in the male (Figure 10).

\subsection{Discussion}

Sô River is one of the western branches of the Ouémé River and also discharges its waters north-west of Lake Nokoué at the lake city of Ganvié (Lalèyè, 1995). This river contains several species (fish) divided into 19 families (Cyrille, 2012). The species that inhabit this river are captured and consumed by the population. However, the quality of water determines the quality of these species.

Physicochemical parameters are factors of verification of the water quality. Thus, temperature, which is one of the main regulators of the metabolic processes that take place in the water, is on average $27.73^{\circ} \mathrm{C}$. A temperature between $24^{\circ} \mathrm{C}$ and $35^{\circ} \mathrm{C}$ allows a good growth of the aquatic species (Dèdjiho, 


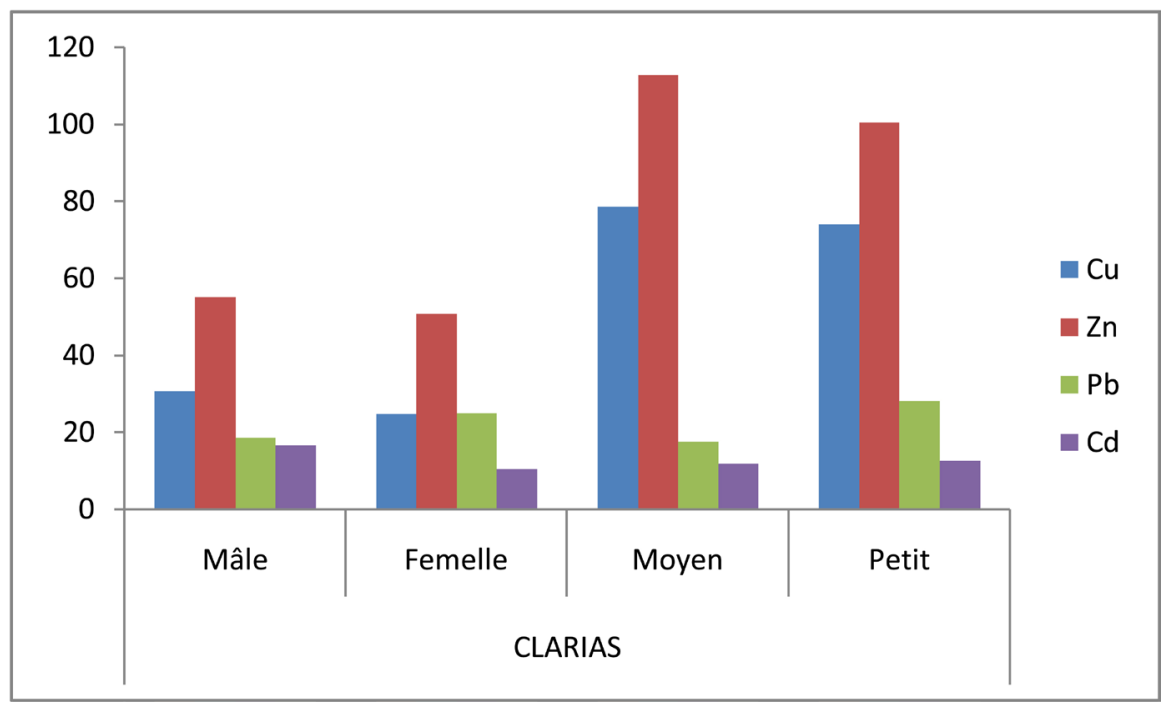

Figure 10. Variation of MTE in Eleotris.

2011). This temperature value is between those found $\left(26.95^{\circ} \mathrm{C}\right.$ and $\left.28.17^{\circ} \mathrm{C}\right)$ on the same river (Koudenoukpo et al., 2017; Cyrille, 2012) these temperature differences depend on the season and time at which the temperature was measured. This value is close to those found in Ouémé delta waters in $2016\left(26.20^{\circ} \mathrm{C}\right)$ and in the Porto-Novo lagoon in 2011 (28.91 $\left.{ }^{\circ} \mathrm{C}\right)$ (Zinsou et al., 2016; Chouti, 2011). This value is lower than the temperature found in 2017 on the coastal $\left(30^{\circ} \mathrm{C}\right)$ (Chouti et al., 2017).

The $\mathrm{pH}$ of a water summarizes the equilibrium stability established between the different forms of carbonic acid and is related to the buffer system developed by carbonates and bicarbonates (El Blidi \& Fekhaoui, 2003; Himmi et al., 2003; Ezzaouaq, 1991). The average value of the $\mathrm{pH}$ of the recorded water is 6.52 . This value is close to the value found in 2012 on the same river (6.15) and in 2016 and in the waters of Delta Ouémé (6.28) (Zinsou et al., 2016; Cyrille, 2012). This value is lower than the value found in 2017 on the same river (7.16), in 2017 in the waters of the coastal lagoon (7.32), in 2014 on the lagoon complex Ahémé-Guézin (7.76 and 9.15) (Koudenoukpo et al., 2017; Chouti et al., 2017; Bocodaho, 2014). This difference can be explained by the nature of the rocks, speciation and availability of MTE, acid precipitation, biological activity, and some releases.

Oxygen is one of the most useful parameters for water and is an excellent indicator of its quality. The average value of dissolved oxygen is $0.4 \mathrm{mg} / \mathrm{L}$. This value is higher than that found in 2011 in the Porto-Novo Lagoon and the one found during the two seasons at Oued Moulouya, Eastern Morocco and in 2012 in the river Sô (5.5) (Cyrille, 2012; Makhoukh et al., 2011; Chouti, 2011). The low recorded content may be due to the high temperature, because the higher the temperature is, the more the dissolved oxygen decreases (Hébert \& Légaré, 2000). It can also be due to eutrophication; the consumption of oxygen by the micro-organisms responsible of the degradation of organic matter can lead to 
oxygen deficit in rivers.

Chemical Oxygen Demand (COD) is the amount of oxygen consumed by chemically oxidizable materials in the water. It is representative of most of the organic compounds but also oxidizable mineral salts (sulphides, chlorides, etc.). The COD content recorded at the water level averages $12.60 \mathrm{mg} / \mathrm{L}$.

The concentration of nitrate and nitrite ions are zero, these results are favorable to aquatic life.

The chemical species $\left(\mathrm{Ca}^{2+}, \mathrm{Cl}^{-}, \mathrm{HCO}_{3}^{-}, \mathrm{Fe}^{2+} / \mathrm{Fe}^{3+}, \mathrm{Mg}^{2+}\right.$ and $\left.\mathrm{NH}_{4}^{+}\right)$are mainly present in the waters of the river. Calcium and magnesium are the dominant ions in the river. The presence of these elements may be due to the bedrock and makes the water hard. $\mathrm{F}^{-}, \mathrm{PO}_{4}^{-}$and $\mathrm{I}^{-}$are present in small proportion.

The average value of TDS is $99 \mathrm{mg} / \mathrm{L}$ and the salinity of the water is zero during the sampling period. This factor explains the absence of some aquatic species and the presence of other species sensitive to salinity.

The metal content in fish is generally specific to species (Gaspic et al., 2002). Differences in metal concentrations between species may be related to habitat, fish mobility, feeding, or other behavioral characteristics (El Morhit et al., 2013).

Zinc is more concentrated in the male than the female, whatever the fish species. This remark is also made for copper except for Tilapia. These results are contrary to those of Sidoumou in 1991 showing that the female gonads concentrate more Copper and Zinc than the male gonads (Sidoumou, 1991). This difference may be related to the nature of the species. The difference in Copper and Zinc concentration between the two sexes may be due to reproductive activity in females. Zinc provides a catalytic and structural role in the body; it is involved in the structure of several metalloenzymes (Drif, 2012). For Kribia and Clarias, Lead is more concentrated in the youngest and for Tilapia, Zinc and Cadmium are more concentrated in the youngest. The higher concentration of metals in younger species generally reflects the short time of the accumulation of these metals in fish, combined with the higher rate of metabolism compared to adult organisms (El Morhit et al., 2013; Cossa et al., 1992).

Significant differences were reported between Zinc and Cadmium levels with higher Zinc concentrations in Tilapia and Eleotris (119 and $136 \mathrm{mg} / \mathrm{kg}$ ), mean levels of Zinc are 13 and $23 \mathrm{mg} / \mathrm{kg}$, mean levels of Cadmium respectively for $T i$ lapia and Eleotris. The same remark is made in 2013 by El Morhit for the two metals on the south Atlantic coast (Morocco) for the species Pagellus acarne, Sardina Pilchardus and Diplodus vulgaris.

The concentration of Cadmium varies from 9.41 to $29.11 \mathrm{mg} / \mathrm{kg}$ and that of Lead varies from 2.48 to $45.43 \mathrm{mg} / \mathrm{kg}$ of fresh weight, these values are much higher than the European standards acceptable in the human diet (Cadmium = $0.1 \mathrm{mg} / \mathrm{kg}$, Lead $=0.5 \mathrm{mg} / \mathrm{kg}$ of fresh weight) (E.C., 2002) and the maximum levels set by the Ministry of Agriculture, Livestock and Fisheries in Order $\mathrm{N}^{\circ} 0362$ MAEP/D-CAB/SGM/DRH/DP/SA (MAEP, 2007) for certain contaminants in foodstuffs in the Republic of Benin (Cadmium $=0.05 \mathrm{mg} / \mathrm{kg}$, Lead $=0.30 \mathrm{mg} / \mathrm{kg}$ ). 
The concentrations of Cadmium and Lead recorded in river fish are higher than those found in the fish of the Porto Novo lagoon, and it already asserts that this poses a real potential danger to the health of the fish consuming populations (Chouti et al., 2011). These results prove that fish of the Sô River consumption is a risk to human health.

\section{Conclusion}

Access to a quantity and quality fish resources remains a major challenge for people in Benin. The majority of the resources are contaminated by metals and their consumptions represent health risks for people. Sampling of water and fish species from Sô River in southern Benin has made it possible to assess the physicochemical parameters of the water and the quality of the river's fish species. At the end of this research, an assessment of the risk of toxicity of the fish of Sô River by contaminations in metals is done. This river contains an abundant fishery resource including several species of fish which are consumed by the populations. The water that conditions the quality of these fish species in the environment is analyzed. The values of the temperatures, $\mathrm{pH}$ and the chemical species present show a good growth of the aquatic species. The concentrations of the metals which are function of the sex and the size of the individual present values higher than the accepted standards. These results indicate risks to fish consumption in the Sô River and need to be further explored in order to protect the health of consumers.

\section{Conflicts of Interest}

The authors declare no conflicts of interest regarding the publication of this paper.

\section{References}

Bocodaho, L. (2014). Evaluation du risque de toxicité et l'état de distribution du zinc, dans des eaux et sédiments du lac Ahémé-Guézin (103 p). Master professionnel, Abomey-Calavi: l'université d'Abomey-Calavi.

Chouti, W. (2011). Study of the Chemical Pollution of a Tropical Lagoon (Waters, Sediments, Fish): Case of the Lagoon of Porto-Novo (Southern Benin) (100 p + Annexes). PhD Thesis, Abomey-Calavi: Faculty of Science and Technology (Fast), University of Abomey-Calavi.

Chouti, W., Chitou, N., Kelome, N., Kpakpo, B. H., Honvou Vlavonou, D., \& Tossou, M. (2017). Caractérisation physico-chimique et étude de la toxicité de la lagune côtière, de Togbin à Grand-Popo (Sud-Ouest Bénin). European Scientific Journal Edition, 13, 131-151. https://doi.org/10.19044/esj.2017.v13n27p131

Chouti, W., Mama, D., Gbaguidi, F., Sagbo, E., Changotade, O., Boukari, M., \& Aminou, T. (2011). The Porto-Novo (South Benin) Lagoon Waters Toxicity Based on Two Methods: The Toxicity Tests on Prawn Larvas of Artemia salina and the Direct Measurement of the Direct Measurement of The Metallic Trace Elements ( $\mathrm{Pb}, \mathrm{Cd}$ and $\mathrm{Hg}$ ) Concentration in the Fish. European Journal of Scientific Research, 53, 306-316.

Cossa, D., Auger, D., Averty, B., Lucon, M., Masselin, P., \& Noel, J. (1992). Flounder 
(Plattichthys flesus) Muscle as an Indicator of Metal and Organochlorine Contamination of French Atlantic Coastal Waters. Ambio, 21, 176-182.

Cyrille, C. (2012). Biodiversity and Exploitation of Some Species of So River Fishes in Benin. Master Thesis, Bobo-Dioulasso: Polytechnic University of Bobo-Dioulasso.

Dèdjiho, A. (2011). Evaluation of the Trophic Chain of a Protected Marine Area Relating to Its Physico-Chemistry: Case of Gbèzoumè in the Municipality of Ouidah. Dea's Memory. Benin: FAST/ UAC.

Drif, F. (2012). Distribution of Trace Metals in Bivalves (Molluscs) in the Gulf of Annaba (North Eastern Algeria) (154 p). Doctoral Thesis Dissertation.

E.C. (2002). European Communities Number 221/2002 of the Commission of February 6, 2002. Bearing Fixation of Maximum Levels for Certain Contaminants in Foodstuffs. Official Journal of the European Communities, 37/4, 37/5 and 37/6.

El Blidi, S., \& Fekhaoui, M. (2003). Hydrologie et dynamique marégraphique de l'estuaire du Sebou (Gharb, Maroc). Bulletin de l'Institut Scientifique, Rabat, 25, 57-65.

El Morhit, M., Belghity, D., \& El Morhit, A. (2013). Metallic Contamination of Pagellus Acarne, Sardina Pilchardus and Diplodus Vulgaris of the South Atlantic Coast (Morocco). Larhyss Journal, 14, 131-148.

Ezzaouaq, M. (1991). Caractérisation hydrodynamique, physico-chimique et bactériologique des eaux superficielles de l'estuaire du Bouregreg (Maroc) soumis aux rejets des villes de Rabat-Salé. Thèse D.E.S. fac. Sci. Rabat, 140.

Fakayode, S. O. (2005). Impact Assessment of Industrial Effluent on Water Quality of the Receiving Alaro River in Ibadan, Nigeria. AJEAM-RAGEE, 10, 1-13.

Gaspic, Z. K., Znovaric, T., Vrgoc, N., Odzak, N., \& Baric, A. (2002). Cadmium and lead in Selected Tissues of Two Commercially Important Fish Species from the Adriatic Sea. Water Research, 36, 5023-5028. https://doi.org/10.1016/S0043-1354(02)00111-2

Hébert, S., \& Légaré, S. (2000). Suivi de la qualité des rivières et petits cours d'eau, Québec. Direction du suivi de l'état de l'environnement, ministère de l'environnement, envirodoq $n^{\circ}$ ENV-20010141, rapport $n^{\circ}$ QE-124, 24p et 3 annexes.

Himmi, N., Fekhaoui, M., Foutlane, A., Bourchic, H., El Maroufy, M., Benazzout, T., \& Hasnaoui, M. (2003). Relazione plankton-parametri fisici chimici in un bacino dimaturazione (laguna mista beni slimane Morocco). Rivesta di idrobiologia. Universitadegli studi di Perugia, departemento di biologia animale ed ecologia laboratoire di idrobiologia “G.B. Grassi” (pp. 110-111).

Katemo, B., Colinet, G., André, L., Chocha, A., Marquet, J.-P., \& Micha, J.-C. (2010). Évaluation de la contamination de la chaîne trophique par les éléments traces $(\mathrm{Cu}, \mathrm{Co}$, $\mathrm{Zn}, \mathrm{Pb}, \mathrm{Cd}, \mathrm{U}, \mathrm{V}$ et As) dans le bassin de la Lufira supérieure (Katanga/RD Congo). Tropicultura, 28, 246-252.

Kiossa, C. (2011). Biodiversité et exploitation de la rivière Sô au Bénin, Mémoire de fin de Master, Université d'Abomey-Calavi (102 p.).

Koudenoukpo, Z. C., Chikou, A., Adandedjan, D., Hazoume, R., Youssao, I., Mensah, G. A., \& Lalèyè, A. P. (2017). Physicochemical Characterization of a Lotic System in the Tropic Region: The Sô River in South Benin, West Africa. Journal of Applied Biosciences, 113, 11111-11122.

Lalèyè, P. A. (1995). Ecologie comparée de deux espèces de Chrisichthys, poissons siluriformes (Claroteidae) du complexe lagunaire lac Nokoué-lagune de Porto-Novo au Bénin (152 p.). Thèse de Doctorat en Sciences, Université de Liège.

Lévêque, C., Paugy, D., \& Teugels, G. G. (1990). Faune des poissons d'eaux douces et saumâtre de l'Afrique de l'Ouest (386 p.). ORSTOM/MRAC Tome 1. Ed. 
Lévêque, C., Paugy, D., \& Teugels, G. G. (1992). Faune des poissons d'eaux douces et saumâtre de l'A frique de l'Ouest (521 p.). Tome, 2. Ed. ORSTOM/MRAC.

MAEP (2007). Arrêté N 0362 MAEP/D-CAB/SGM/DRH/DP/SA portant fixation des teneurs maximales pour certains contaminants dans les denrées alimentaires en République du bénin. Ministère de l'Agriculture, de l'Elevage et de la Pêche du 30 octobre 2007.

Makhoukh, M., Sbaa, M., Berrahou, A., \& Clooster, Van. (2011) Contribution to the Physico-Chemical Study of Superficial Waters in Oued Moulouya (Eastern Morocco). Larhyss Journal, No. 9, 149-169.

Ogindo, B. A. (2001). Heavy Metal Polluants and Their Concentrations in Fish (Barbus Species) in Sosiani River, Kenya. Discovery and Innovation, 13, 178-197.

Ouédraogo, A. (2016). Evaluation de la teneur en métaux lourds dans les tissus du Tilapia du nil (Oreochromis liloticus) et du poisson chat africain (Clarias sp.) d'eau douce Burkina-faso.

Sidoumou, Z. (1991). Qualité des eaux du littoral mauritanien: Dude des metaux traces chez deux mollusques bivalves (Venus verrucosa et Donax rugosus) (184 p.). Thèse de Doctorat sciences de la vie.

Tabinda, A. B., Hussain, M., Ahmed, I., \& Yassar, A. (2010). Accumulation of Toxic and Essential Trace Metals in Fish and Prawns from Keti Bunder Thatter District, Sindh Pakistan. Journal of Zoology, 42, 631-638.

Zinsou, H., Attingli, A., Gnohossou, P., Adandedjan, D., \& Lalèyè, P. (2016). Physico-Chemical Characteristics and Water Pollution of the Oueme Delta in Benin. Journal of Applied Biosciences, 97, 9163-9173. 